\title{
THE EVALUATION OF THE EFFECT OF VITAMIN E ON NITROSO- OXIDATIVE PROCESSES IN MUCOUS MEMBRANES OF THE DIGESTIVE ORGANS UNDER THE CONDITIONS OF CYCLOOXYGENASE BLOCKAGE ON THE BACKGROUND OF THE LOW INTENSITY X-RAY IRRADIATION
}

Introduction. The simultaneous effect of several ulcerogenic factors, different due to their mechanism of action on the mucous membranes of the digestive organs needs deep elucidation. The studies were focused on the combined effect of the low intensity $X$-ray irradiation and cyclooxygenase blockage. It is important to evaluate the antioxidant effect of vitamin $E$ under the conditions of simultaneous effect of different pro-inflammatory factors, acting on the nitroso-oxidative processes.

The aim of the study - to investigate the effect of vitamin $E$ on nitroso-oxidative processes in the mucous membranes of the digestive organs under the action of the low intensity X-ray irradiation and COX blockage.

Research Methods. In the homogenates of the mucous membranes of stomach, small and large intestine in rats ( $n=64)$ the activity of NO-synthase, arginase, myeloperoxidase, superoxide dismutase, catalase, TBA-active products, nitrite-anion content and sum of nitrites and nitrates were determined.

Results and Discussion. It was established that the effect of vitamin $E$ on the background of the low intensity $X$-ray irradiation resulted in the decrease of iNOS activity level $(p<0.05)$ and nitrite-anion content $(p<0.05)$ and increase of catalase and MPO activity in the mucous membranes of the digestive organs compared to indices obtained under the conditions of X-ray irradiation. Blockage of COX activity by indometacin on the background of the introduction of vitamin $E$ and simultaneous effect of the low intensity $X$-ray irradiation revealed the peculiarities of antioxidant action of vitamin $E$ in the mucous membranes of the digestive organs.

Conclusions. Under the conditions of COX blockage on the background of the low intensity X-ray irradiation the level of lipid peroxidation processes increased, iNOS and cNOS activity decreased compared to indices under the independent effect of irradiation, whereas compared to data under the effect of indometacin lipid peroxidation processes and iNOS activity decreased. Vitamin E exerts antioxidant effect under the conditions of ulcerative action of indometacin on the background of the $X$-ray irradiation.

KEY WORDS: X-ray irradiation; nitroso-oxidative processes; mucous membranes of the digestive organs; vitamin E.

INTRODUCTION. The evaluation of the simultaneous effect of the ulcerative factors, different due to their mechanism of action is one of the actual directions in gastroenterology. The use of nonsteroidal antiinflammatory drugs - blockers of COX-1/COX-2 is among the factors, causing the development of erosive-ulcerative damage in stomach and small intestine $[1,2]$. Another factor, causing functional alterations of the digestive organs is the effect of chronic irradiation, which mechanism of action implicates free radical reactions in cells and the development of nitroso-oxidative stress [3, 4]. At that, the mucous barrier in mucous membranes of the digestive organs gets disrupted, processes

(c) Kh. M. Ilnytska, L. O. Datsyuk, O. Ya. Sklyarov, 2018. of growth and differentiation get inhibited, proinflammatory processes get activated $[5,6]$.

Vitamin $E$ is one of the key antioxidants, the effect of which is associated with the binding of free radicals (oxygen lipid, nitrogen oxide etc) [7]. However, the manifestations of the antioxidant effect of vitamin $E$ on the background of the low intensity $X$-ray irradiation and simultaneous blockage of COX-1/COX-2 needs further elucidation.

The aim of the study - to investigate the effect of vitamin $E$ on nitroso-oxidative processes in mucous membranes of the digestive organs under the conditions of the low intensity X-ray irradiation and cOX blockage. 
RESEARCH METHODS. The studies were conducted on white male rats weighing 200-240 g $(n=64)$ accordingly to ethical requests, established by the European Convention on the Protection of the Vertebrate Animals, Used for Experimental and Scientific Purposes. The animals were kept in vivarium under the appropriate light conditions, temperature regimen and standard diet. Before the experiments the rats had unlimited access to water during $20 \mathrm{~h}$.

The animals were divided into 6 groups: the $1^{\text {st }}-$ control animals $(n=10)$, the $2^{\text {nd }}-$ animals $(n=8)$, who during 20 days were irradiated in daily dose 1 sGy [8]; the third - animals $(n=12)$, who twice per week per os were introduced vitamin E (30 mg/kg, $\left(( \pm)\right.$ - $\alpha$-tocopherol, $\mathrm{C}_{29} \mathrm{H}_{50} \mathrm{O}_{2}$, "Sigma") on the background of irradiation; the fourth - animals $(n=12)$, who on the $20^{\text {th }}$ day on the background of the $\mathrm{X}$-ray irradiation were injected indometacin $(10 \mathrm{mg} / \mathrm{kg})$; the fifth - animals ( $\mathrm{n}=12)$, who on the 20th day on the background of X-ray irradiation and vitamin $\mathrm{E}$ were introduced indometacin; the sixth animals $(n=10)$, who were intragastrically introduced indometacin (10 mg/kg, "Sopharma", Bulgaria).

Anesthetised with sodium thiopental ( $40 \mathrm{mg} / \mathrm{kg}$ ), the animals were decapitated, front abdominal wall was cut along the white abdominal line. The stomach, small and large intestine were washed by the saline. The mucous membranes of the investigated organs were mechanically removed and homogenized for the determination of biochemical parameters.

In homogenates of the mucous membrane of stomach (MMS), mucous membrane of small intestine (MMSI) and mucous membrane of large intestine (MMLI) the activity of NO-synthase was measured due to the determination of NADPH [9], arginase due to the quantity of produced urea [10], myeloperoxidase (MPO) was determined due to

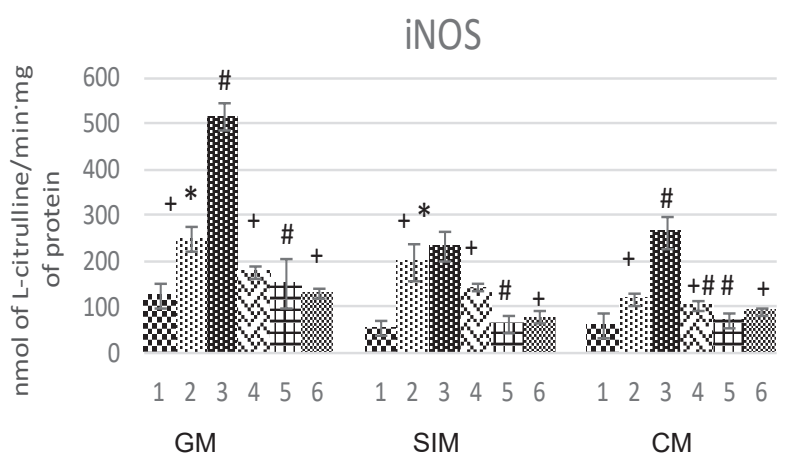

the reaction with o-dianisidine [11], superoxide dismutase (SOD) due to the reaction of nitroblue tetrazolium [12], catalase due to the reaction of hydrogen peroxide with ammonia molybdate [13], TBA-active products content [14], nitrite-anion due to the reaction with Griess reagent [15] and sum of nitrites and nitrates [16].

Statistical procession of the experimental data was performed using the applied program ANOVA "Statistica". The difference at $P<0.05$ was supposed to be statistically significant.

RESULTS AND DISCUSSION. The effect of the low intensity $\mathrm{X}$-ray irradiation in the total dose of $20 \mathrm{sGy}$ on the $20^{\text {th }}$ day caused the increase of the level of inducible NO-synthase activity (iNOS) $(p<0.05)$ and nitrite-anion content $(p<0.05)$ in mucous membranes of the digestive organs compared to control group indices. Activity of cNOS and arginase did not change significantly (Fig. 1, 2). Simultaneously the TBA-active products content and MPO activity increased in digestive organs. The changes of the antioxidant enzymes activity reflected in the increase of SOD activity in MMS and increased catalase activity in the digestive organs, that was mediated by the increase of prooxidant processes $[17,18]$.

As it was mentioned above, nonsteroidal antiinflammatory drugs are often used on the background of the low intensity X-ray irradiation. The independent effect of COX-1/COX-2 blocker indometacin significanty affected the status of NOsynthase system - iNOS activity acutely rose in all investigated organs, simultaneously cNOS activity decreased. Along with the increase of iNOS activity in the mucous membranes of the investigated organs nitrite-anion content and the sum of nitrites and nitrates increased compared with the indices of the control group of animals. Arginase activity in

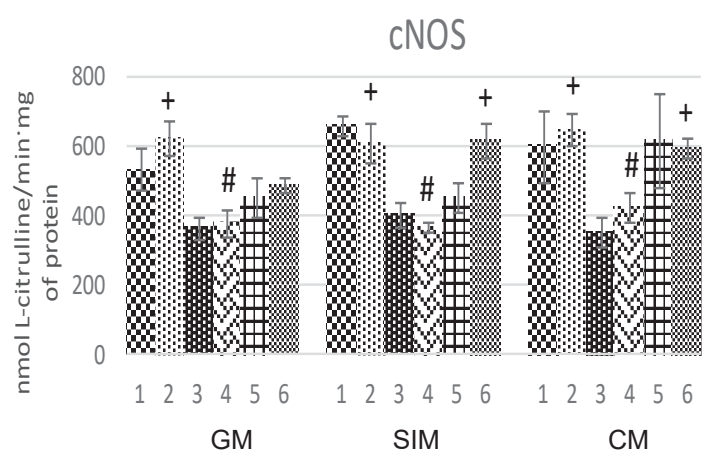

Fig. 1. The changes of iNOS and cNOS activity in mucous membranes of stomach (GM), small (SIM) and large intestine (CM) under the effect of vitamin $E$ on the background of the low intensity X-ray irradiation and COX blockage $(n=64, M \pm m)$. 1 - control group animals, 2 - effect of the low intensity X-ray irradiation; 3- effect of indometacin; 4 - effect of indometacin on the background of the low intensity $X$-ray irradiation; 5 - effect of vitamin $E$ derivative on the background of the low intensity X-ray irradiation; 6 - effect of vitamin $E$ on the background of the low intensity X-ray irradiation and indometacin. The reliability of the differences : * $p<0.05$ - compared to control group ; ${ }^{*} p<0.05$ - compared to indices in the low intensity $X$-ray irradiation group; ^ $p<0,05$ - compared to indices in the low intensity $X$-ray irradiation and indometacin effect group; $+p<0.05-$ compared to indices under the effect of indometacin group. 

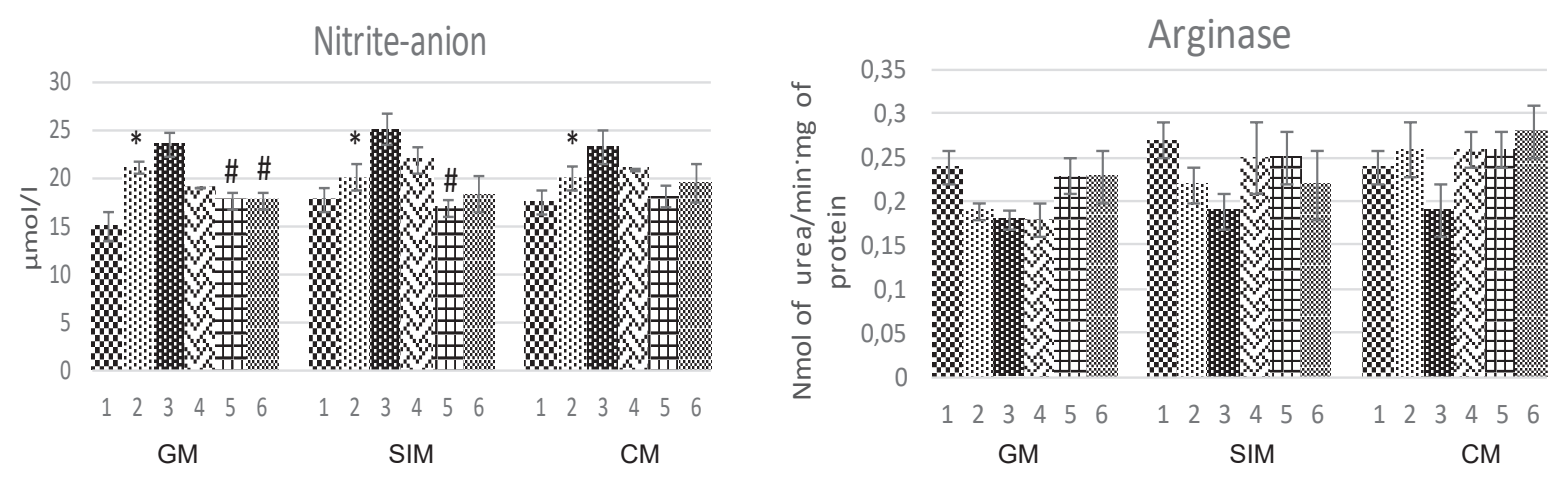

Fig. 2. The changes of nitrite-anion content and arginase activity in mucous membranes of stomach (GM), small (SIM) and large intestine (CM) under the effect of vitamin $E$ on the background of the low intensity $X$-ray irradiation and COX blockage $(n=64, M \pm m) .1$ - control group animals, 2 - effect of the low intensity X-ray irradiation; 3- effect of indometacin; 4 - effect of indometacin on the background of the low intensity X-ray irradiation; 5 - effect of vitamin E derivative on the background of the low intensity X-ray irradiation; 6 - effect of vitamin $E$ on the background of the low intensity X-ray irradiation and indometacin. The reliability of the differences : * $p<0.05$ - compared to control group ; $p<0.05$ - compared to indices in the low intensity X-ray irradiation group; ${ }^{\wedge} p<0,05$ - compared to indices in the low intensity X-ray irradiation and indometacin effect group; $+p<0.05-$ compared to indices under the effect of indometacin group.

all mucous membranes had tendency to decrease. Under the effect of indometacin the increase content of the TBA-active products, MPO and SOD activity in all investigated organs. The results obtained by us are in coincidence with the data of the other authors towards the action of indomethacin on the mucous membranes of the digestive organs $[19,20]$.

Evaluating the effect of indometacin on the background of the low intensity X-ray irradiation compared to the indices of the independent effect of the low intensity X-ray irradiation to the increase of the TBA-active products content in MMS was found (for $11 \%, p<0.05$ ) and MMLI (for $13 \%$, $\mathrm{p}<0.05)$ and MPO activity in MMLI $(67 \%, \mathrm{p}<0.05)$. The changes of the antioxidant defense system enzymes had organospecific character. Activity of iNOS and cNOS under the conditions of COX blockage on the background of low intensity X-ray irradiation decreased $(p<0.05)$. Nitrite-anion content and arginase activity did not change significantly compared to indices obtained under independent effect of irradiation. Comparing with indices obtained under the effect of indomethacin, the level of iNOS activity, nitrite-anion content, sum of nitrates and nitrites and TBA-active products content were significantly lower.

Hence, blockage of COX on the background of the low intensity X-ray irradiation compared to independent effect of the low intensity $X$-ray irradiation results in the increase of the activity of lipid peroxidation processes and decrease of the activity of iNOS and cNOS, whereas compared to the independent effect of indometacin its proinflammatory effect decreased.

Effect of vitamin $E$ on the background of the low intensity X-ray irradiation caused the decrease of the activity level of iNOS in MMS for $27 \%(p<0.05)$, in $\mathrm{MMSI}$ - for $32 \%(\mathrm{p}<0.05)$, in MMLI - for $39 \%$ $(p<0.05)$, simultaneously nitrite-anion content decreased $(p<0.05)$ compared to indices under the effect of X-ray irradiation. The tendency to decrease of the TBA-active products content and multidirectional changes of SOD and catalase activity were noted - SOD activity decreased for $20 \%(p<0.05)$ in MMS and for $17 \%(p<0.05)$ in MMLI, whereas catalase activity rose in all investigated organs (Fig. 3, 4). Under the conditions of vitamin E administration MPO activity increased in MMLI.

Hence, under mentioned conditions vitamin $\mathrm{E}$ on one hand exerted antioxidant effect, manifested by iNOS activity decrease, tendency to decrease of TBA-active products content and increase of catalase activity, whereas prooxidant effect manifested in the increase of MPO activity.

For deeper elucidation of the character of vitamin E effect it was studied under the conditions of simultaneous influence of $\mathrm{X}$-ray irradiation and COX-blockage. Vitamin E administration and simultaneous effect of X-ray irradiation and COX blockage resulted in the decrease of TBA-active products content for $14 \%(p<0.05)$, in MMSI - for $11 \%(p<0.05)$, in MMLI - for $11 \%(p<0.05)$ and iNOS activity - in MMS for $26 \%(p<0.05)$, in MMSI for $45 \%(p<0.05)$, in MMLI - for $12 \%(p>0.05)$; SOD activity also decreased mainly in MMSI and MMLI compared to relevant indices under the effect of indometacin on the background of the low intensity X-ray irradiation, whereas the level of iNOS, arginase, MPO, SOD, catalase activity, TBA-active products and nitrite-anion content did not change compared to indices under the effect of vitamin $\mathrm{E}$ on the background of the low intensity X-ray irradiation.

Thus, introduction of vitamin $\mathrm{E}$ on the background of the low intensity X-ray irradiation twice 
TBA-active products

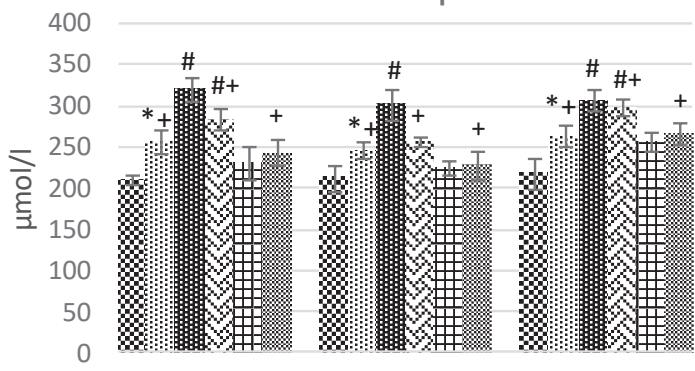

$123456 \quad 123456 \quad 123456$

GM

SIM

CM

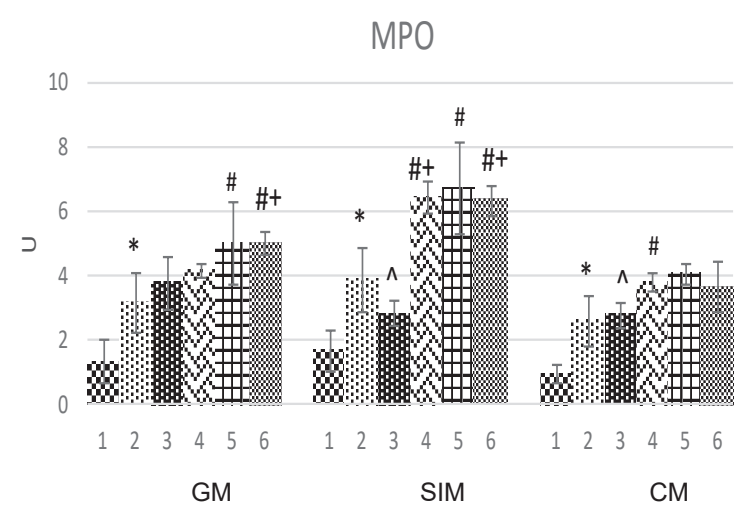

Fig. 3. The changes of TBA-active products content and MPO activity in mucous membranes of stomach (GM), small (SIM) and large intestine (CM) under the effect of vitamin E on the background of the low intensity X-ray irradiation and COX blockage $(n=64, M \pm m) .1$ - control group animals, 2 - effect of the low intensity X-ray irradiation; 3- effect of indometacin; 4 - effect of indometacin on the background of the low intensity X-ray irradiation; 5 - effect of vitamin $E$ derivative on the background of the low intensity X-ray irradiation; 6 - effect of vitamin $E$ on the background of the low intensity $X$-ray irradiation and indometacin. The reliability of the differences: * $p<0.05$ - compared to control group; ${ }^{*} p<0.05$ - compared to indices in the low intensity X-ray irradiation group; ^ $\mathrm{p}<0.05$ - compared to indices in the low intensity X-ray irradiation and indometacin effect group; $+p<0.05$ - compared to indices under the effect of indometacin group.
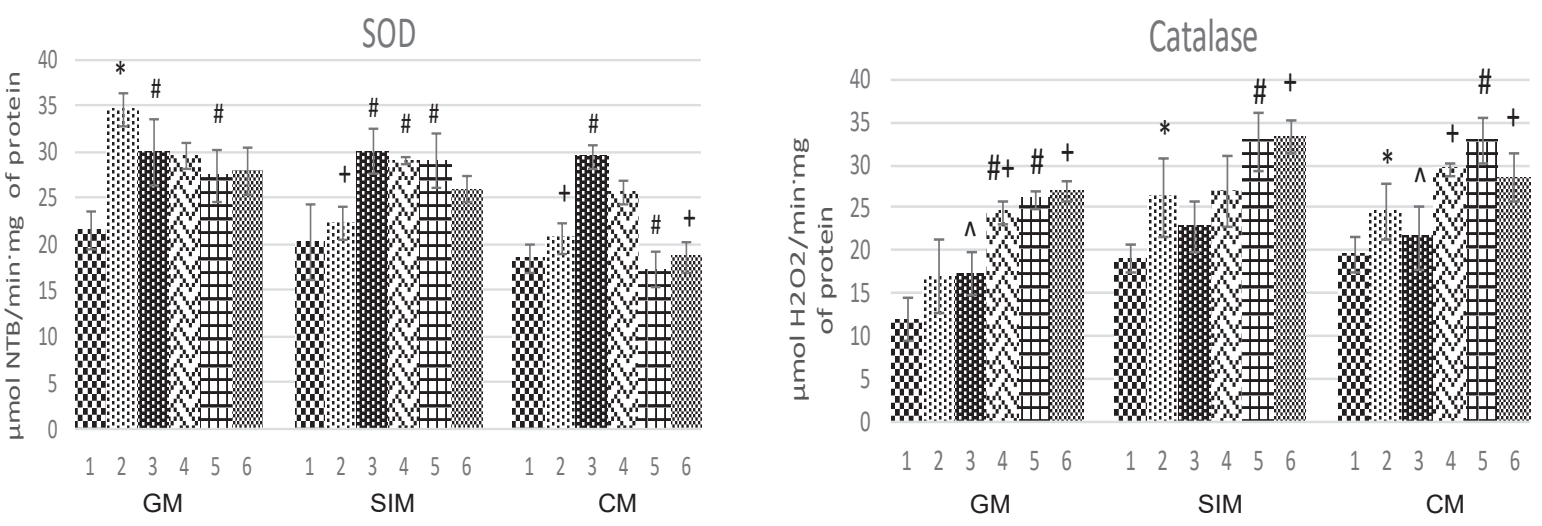

Fig. 4. The changes of SOD and catalase activity in mucous membranes of stomach (GM), small (SIM) and large intestine (CM) under the effect of vitamin $E$ on the background of the low intensity X-ray irradiation and COX blockage $(n=64, M \pm m)$. 1 - control group animals, 2 - effect of the low intensity X-ray irradiation; 3- effect of indometacin; 4 - effect of indometacin on the background of the low intensity X-ray irradiation; 5 - effect of vitamin E derivative on the background of the low intensity $\mathrm{X}$-ray irradiation; 6 - effect of vitamin $\mathrm{E}$ on the background of the low intensity X-ray irradiation and indometacin. The reliability of the differences : * $p<0.05$ - compared to control group ; ${ }^{*} p<0.05$ - compared to indices in the low intensity $X$-ray irradiation group; ^ $p<0.05$ - compared to indices in the low intensity $X$-ray irradiation and indometacin effect group; $+p<0.05-\operatorname{compared}$ to indices under the effect of indometacin group.

per week during 3 weeks showed the peculiarities of its effect on the NO-synthase system in MMLI, manifested in the decrease of the activity level of iNOS and nitrite-anion content, status of pro- and antioxidant system characterised by the tendency to decrease of TBA-active products content, decrease of SOD activity and increase of catalase activity, at that MPO activity increased.

CONCLUSIONS. 1. Effect of vitamin E on the background of the low intensity X-ray irradiation caused the decrease of the activity level of iNOS $(p<0.05)$ and nitrite-anion content $(p<0.05)$ in mucous membranes of the digestive organs compared to indices under the X-ray irradiation. The tendency to decrease of TBA-active products content and SOD activity was revealed, whereas catalase and MPO increased in all digestive organs.
2. Under the conditions of COX blockage on the background of the low intensity X-ray irradiation the intensification of lipid peroxidation processes was found, whereas iNOS and cNOS decreased compared to indices uder the independent effect of irradiation, whereas compared to the indices under the effect of indometacin TBA-active products content and iNOS activity were lower, determinating the peculiarities of the modeling effect of the low intensity X-ray irradiation on nitroso-oxidative processes and system of COX/prostaglandins.

3. Blockage of COX activity by indometacin on the background of vitamin $E$ introduction and simultaneous effect of X-ray irradiation caused the decrease of TBA-active products content $(p<0.05)$ in the mucous membranes of the digestive organs, SOD activity level mainly in MMSI and MMLI compared to relevant indices under the effect of indo- 
metacin on the background of the low intensity X-ray irradiation; changes of iNOS, arginase, MPO, SOD catalase activity, TBA-active products and nitriteanion content were not revealed compared with the indices under the effect of vitamin $E$ on the background of the low intensity X-ray irradiation, stating the antioxidant effect of vitamin $\mathrm{E}$ under the conditions of ulcerative action of indometacin.

\section{LITERATURE}

1. NSAID-gastroenteropathy: new aspects of pathogenesis and prevention / R.W. Blackler, B. Gemici, A. Manko [et al.] // Curr. Opin. Pharmacol. -2014. - 19. P. 11-16.

2. Changes of nitric oxide system and lipid peroxidation parameters in the digestive system of rats under conditions of acute stress, and use of nonsteroidal antiinflammatory drugs / I. Fomenko, T. Bondarchuk, V. Emelyanenko [et al.] // Current Issues in Pharmacy and Medical Sciences. - 2015. - 28, No. 1. - P. 37-41.

3. Szumiel I. Ionizing radiation-induced oxidative stress, epigenetic changes and genomic instability: the pivotal role of mitochondria // Int. J. Radiat. Biol. -2015. 91, No. 1. - P. 1-12.

4. Pisoschi A.M. The role of antioxidants in the chemistry of oxidative stress: A review / A. M. Pisoschi, A. Pop // Eur. J. Med. Chem. - 2015. - 5, No. 97. - P. 55-74.

5. Epicatechin ameliorates ionising radiation-induced oxidative stress in mouse liver / M. Sinha, D.K. Das, K. Manna [et al.] // Free Radic. Res. - 2012. - 46, No. 7. P. 842-849.

6. Effect of antioxidant supplementation on digestive enzymes in radiation induced intestinal damage in rats / M. Anwar, N. Nanda, A. Bhatia [et al.] // Int. J. Radiat. Biol. - 2013. - 89, No. 12. - P. 1061-1070.

7. The rise, the fall and the renaissance of vitamin $E /$ A. Azzi, S. N. Meydani, M. Meydani [et al.] // Arch. Biochem. Biophys. - 2016. - 595. - P. 100-108.

8. Ефект введення неселективного інгібітора NO-синтази за умов низькоінтенсивного рентгенівського опромінення / Л. О. Дацюк, Ю.В.Перетятко, У. В. Старенко [та ін.] // Біол. студії. - 2009. - 3, № 3. C. $51-58$.

9. Boyde J. R. Optimization of conditions for the colorimetric determination of citrulline, using diacethyl monoxim / J. R. Boyde, M. Rahmotullah // Anal. Biochem. - 1980. - No. 107. - P. 424-431.

10. Geyer J. W. Rapid method for determination of arginase activity in tissue homogenates / J. W. Geyer, D. Dabich // Anal. Biochem. - 1971. - 39, No. 2. P. 412-417.

11. Bradley P. P. Cellular and extracellular myeloperoxidase in pyogenic inflammation / P. P. Bradley, R. D. Christensen, G. Rothstein // Blood. - 1982. No. 60. - P. 618-622.
12. Чевари С. Определение антиоксидантных параметров крови и их диагностическое значение в пожилом возрасте / С. Чевари, Т. Андял, Я. Штренгер // Лаб. дело. - 1991. - № 10. - С. 9-13.

13. Метод определения активности каталазы / М. А. Королюк, Л. И. Иванова, И. Г. Майорова, В. Е. Токарев // Лаб. дело. - 1988. - № 1. - С. 16-19.

14. Тимирбулатов Р. А. Метод повышения интенсивности свободнорадикального окисления липидсодержащих компонентов крови и его диагностическое значение / Р. А. Тимирбулатов, Е. И. Селезнев // Лаб. дело. - 1981. - № 4. - С. 209-211.

15. Green L. C. Analysis of nitrate, nitrite and (1515) nitrate in biological fluids / L. C. Green, A. W. David // Anal. Biochem. - 1982. - 126. - P. 131-138.

16. Кіселик І. О. Особливості визначення нітритів та нітратів в периферичній крові у хворих на вірусні гепатити та при синдромі жовтяниці іншої етіології / І. О. Кіселик, М. Д. Луцик, Л. Ю. Шевченко // Лаб. діагностика. - 2001. - № 3. - С. 43-45.

17. Вплив похідного 1,4-нафтохінону та стресу на тлі дії низькоінтенсивного рентгенівського опромінення на нітрозо-оксидативні процеси у слизових оболонках органів травлення в щурів / Х. М. Ільницька, Л. О. Дацюк, В. П. Новіков [та ін.] // Мед. та клініч. хімія. - 2015. - 17 (65), № 4. - С. 5-9.

18. The influence of 1.4-naphtoquinone derivative and of vitamin $E$ on nitroso-oxidative processes in digestive organ mucous membranes under the conditions of cyclooxygenase blockage, and against the background of low intensity X-ray irradiation / Kh. Ilnytska, L. Datsyuk, V. Novikov [et al.] // Curr. Issues Pharm. Med. Sci. 2016. - 29, No. 3. - P. 127-131.

19. Nasadyuk C. Thymohexin exhibits cytoprotective effect in experimental gastric lesions in rats both through the inhibition of inducible nitric oxide synthase and reduction of oxidative mucosal damage / C. Nasadyuk, A. Sklyarov // Regulatory Peptides. - 2013. - 180. P. 50-57.

20. Ilkiv I. I. The influence of novel 4-thiazolidinone derivaties in cytoprotective mechanisms of small intestine undernsaid-induced damage / I. I. Ilkiv, R. B. Lesyk, O. Y. Sklyarov // The Ukrainian Biochemical Journal. 2016. - 88. - P. 99-104. 


\section{REFERENCES}

1. Blackler, R.W., Gemici, B., Manko, A., \& Wallace, J.L. (2014). NSAID-gastroenteropathy: new aspects of pathogenesis and prevention. Curr. Opin. Pharmacol. 19, 11-16.

2. Fomenko, I., Bondarchuk, T., Emelyanenko, V., Denysenko, N., Sklyarov, P., Ilkiv, I., Lesyk, R., \& Sklyarov, A. (2015). Changes of nitric oxide system and lipid peroxidation parameters in the digestive system of rats under conditions of acute stress, and use of nonsteroidal anti-inflammatory drugs. Current Issues in Pharmacy and Medical Sciences, 28 (1), 37-41.

3. Szumiel, I. (2015). Ionizing radiation-induced oxidative stress, epigenetic changes and genomic instability: the pivotal role of mitochondria. Int. J. Radiat. Biol. 91 (1), 1-12.

4. Pisoschi, A.M., \& Pop, A. (2015). The role of antioxidants in the chemistry of oxidative stress: A review. Eur. J. Med. Chem. 5, (97), 55-74.

5. Sinha, M., Das, D.K., Manna, K., Datta, S., Ray, T., Sil, A.K., \& Dey, S. (2012). Epicatechin ameliorates ionising radiation-induced oxidative stress in mouse liver. Free Radic. Res. 46 (7), 842-849.

6. Anwar, M., Nanda, N., Bhatia, A., Akhtar, R., \& Mahmood, S. (2013). Effect of antioxidant supplementation on digestive enzymes in radiation induced intestinal damage in rats. Int. J. Radiat. Biol. 89 (12), 1061-1070.

7. Azzi, A., Meydani, S.N., Meydani, M., \& Zingg, J.M. (2016) The rise, the fall and the renaissance of vitamin $E$. Arch. Biochem. Biophys., 595, 100-108.

8. Datsiuk, L.O., Peretiatko, Yu.V., Staranko, U.V., \& Sybirna, N.O. (2009). Effect vvedennia neselektyvnoho inhibitora NO-syntazy za umov nyzkointensyvnoho renthenivskoho oprominennia [Activity of NO-synthase and content of stable methabolic nitric oxide products in peripheral blood leukocytes under the chronic x-ray radiation and administration of I-arginine]. Biolohichni studii - Biological Studio, 3(3), 51-58 [in Ukrainian].

9. Boyde, J.R., \& Rahmotullah, M. (1980). Optimization of conditions for the colorimetric determination of citrulline, using diacethyl monoxim. Anal. Biochem. 107, 424-431.

10. Geyer, J.W., \& Dabich, D. (1971) Rapid method for determination of arginase activity in tissue homogenates. Anal. Biochem. 39 (2), 412-417.

11. Bradley, P.P., Christensen, R.D., \& Rothstein, G. (1982). Cellular and extracellular myeloperoxidase in pyogenic inflammation. Blood. 60, 618-622.

12. Czevari, S., Andyal, T., \& Chtrenger, Ya. (1991). Opredeleniye antioksidantnykh parametrov krovi i ikh diagnosticheskoe znachenie $v$ pozulom vozraste [Determination of the antioxidant parameters of blood and their diagnostic significance in old age]. Laboratornoye delo Laboratory Work,10, 9-13 [in Russian].

13. Korolyuk, M.A., Ivanova, L.I., \& Mayorova, I.G. (1988). Metod opredeleniya aktivnosti katalazu [Method determination of catalase activity]. Laboratornoye delo Laboratory Work, 1, 16-19 [in Russian].

14. Timirbulatov, R.A., \& Seleznyov, E.I. (1981). Metod povysheniya intensivnosti svobodnoradikalnogo okisleniya lipidsoderzhashchikh komponentov krovi i ego diagnosticheskoe znachenie [Method of the intensivity increase of free radical oxidation of lipid-containing blood components and their diagnostic significance] Laboratornoye delo - Laboratory Work, 4, 209-211 [in Russian].

15. Green, L.C., \& David, A.W. (1982). Analysis of nitrate, nitrite and (1515) nitrate in biological fluids. Anal. Biochem. 126, 131-138.

16. Kiselyk, I.O., Lutsyk, M.D., \& Shevchenko, L.Yu. (2001). Osoblyvosti vyznachennia nitrytiv ta nitrativ v periferiinii krovi u khvorykh na virusni hepatyty ta pry syndromi zhovtianytsi inshoi etiolohii [The peculiarities of the determination of nitrates and nitrites in peripheral blood of patients with viral hepatitis and jaundice syndrome of other ethiology]. Laboratorna diahnostyka Laboratory Diagnostics, 3, 43-45 [in Ukrainian].

17. Innytska, Kh.M., Datsiuk, L.O., Novikov, V.P., Fihurka, O.M., \& Skliarov, O.Ya. (2015). Vplyv pokhidnoho 1,4-naphtochinonu ta stresu na tli dii nyzkointensyvnoho renthenivskoho oprominennia na nitrozo-oksudatyvni protsesy u slyzovykhh obolonkakh orhaniv travlennia [The influence of 1.4-naphtoquinone derivative and stress on the background of low intensity x-ray irradiation on nitroseoxidative processes in mucous membranes of digestive organs in rats]. Medychna ta klinichna khimiia Medical and Clinical Chemistry, 17 (4), 5-9 [in Ukrainian].

18. Ilnytska, K., Datsyk, L., Novikov, V., Denysenko, N., \& Sklyarov, A. (2016). The influence of 1.4-naftoquinone derivative and of vitamin $\mathrm{E}$ on nitroso-oxidative processes in digestive organ mucous membranes under the condition of low intensity X-ray irradiation. Current Issues in Pharmacy and Medical Sciences. 29 (3), 127131.

19. Nasadyuk, C., \& Sklyarov, A. (2013). Thymohexin exhibits cytoprotective effect in experimental gastric lesions in rats both through the inhibition of inducible nitric oxide synthase and reduction of oxidative mucosal damage. Regulatory Peptides.180, 50-57.

20. Ilkiv, I.I., Lesyk, R.B., \& Sklyarov, O.Y. (2016). The influence of novel 4-thiazolidinone derivaties in cytoprotective mechanisms of small intestine undernsaidinduced damage. The Ukrainian Biochemical Journal, 88, 99-104. 


\section{ОЦІНКА ВПЛИВУ ВІТАМІНУ Е НА НІТРОЗО-ОКСИДАТИВНІ ПРОЦЕСИ У СЛИЗОВИХ ОБОЛОНКАХ ОРГАНІВ ТРАВЛЕННЯ ЗА УМОВ БЛОКУВАННЯ ЦИКЛООКСИГЕНАЗИ НА ТЛІ ДІЇ НИЗЬКОІНТЕНСИВНОГО РЕНТГЕНІВСЬКОГО ОПРОМІНЕННЯ}

\section{Резюме}

Вступ. Потребує поглибленого вивчення одночасний вплив декількох різних за своїм механізмом ульцерогенних фракторів на слизову оболонку органів травлення, серед них - низькоінтенсивне рентгенівське опромінення та блокування циклооксигенази. Важливо оцінити антиоксидантний вплив вітаміну Е за умов одночасної дії різних прозапальних чинників, що впливають на нітрозо-оксидативні процеси.

Мета дослідження - вивчити вплив вітаміну Е на нітрозо-оксидативні процеси у слизових оболонках органів травлення щурів за умов дії низькоінтенсивного рентгенівського опромінення та блокування циклооксигенази.

Методи дослідження. У гомогенатах слизових оболонок шлунка, тонкої і товстої кишок щурів ( $n=64)$ визначали активність синтази оксиду азоту, аргінази, мієлопероксидази, супероксиддисмутази, каталази, вміст ТБК-активних продуктів, нітрит-аніона та суму нітритів і нітратів.

Результати й обговорення. Встановлено, що дія вітаміну Е на тлі низькоінтенсивного рентгенівського опромінення призводила до зниження рівня активності індуцибельної синтази оксиду азоту $(p<0,05)$ та вмісту нітрит-аніона $(p<0,05)$ і підвищення активності каталази $(p<0,05)$ та мієлопероксидази $(p<0,05)$ порівняно з показниками рентгенівського опромінення. Блокування активності циклооксигенази індометацином на тлі введення вітаміну Е та одночасної дії низькоінтенсивного рентгенівського опромінення виявило особливості антиоксидантного впливу вітаміну Е у слизових оболонках органів травлення.

Висновки. За умов блокування циклооксигенази індометацином на тлі низькоінтенсивного рентгенівського опромінення рівень процесів ліпопероксидації зростає, тоді як активність індуцибельної і конститутивної синтаз оксиду азоту зменшується порівняно з показниками при самостійній дії рентгенівського опромінення, а порівняно з даними при дії індометацину рівень процесів пероксидного окиснення ліпідів та активність індуцибельної синтази оксиду азоту знижуються. Вітамін Е чинить антиоксидантний вплив при цитоушкоджувальній дії індометацину та на тлі дії рентгенівського опромінення.

КЛЮЧОВІ СЛОВА: рентгенівське опромінення; нітрозо-оксидативні процеси; слизові оболонки органів травлення; вітамін Е.

К. Н. Ильницкая, Л. А. Дацюк ${ }^{1}$ А. Я. Скляров ЛЬВОВСКИЙ НАЦИОНАЛЬНЫЙ МЕДИЦИНСКИЙ УНИВЕРСИТЕТ ИМЕНИ ДАНИЛА ГАЛИЦКОГО ЛЬВОВСКИЙ НАЦИОНАЛЬНЫЙ УНИВЕРСИТЕТ ИМЕНИ ИВАНА ФРАНКО

\section{ОЦЕНКА ВЛИЯНИЯ ВИТАМИНА Е НА НИТРОЗО-ОКСИДАТИВНЫЕ ПРОЦЕССЫ В СЛИЗИСТЫХ ОБОЛОЧКАХ ОРГАНОВ ПИЩЕВАРЕНИЯ ПРИ БЛОКИРОВАНИИ ЦИКЛООКСИГЕНАЗЫ НА ФОНЕ ДЕЙСТВИЯ НИЗКОИНТЕНСИВНОГО РЕНТГЕНОВСКОГО ОБЛУЧЕНИЯ}

\section{Резюме}

Вступление. Требует углубленного изучения одновременное влияние нескольких разных по своему механизму ульцерогенных фракторов на слизистую оболочку органов пищеварения, среди них - низкоинтенсивное рентгеновское облучение и блокирование циклооксигеназы. Важно оценить антиоксидантное влияние витамина Е при одновременном действии разных провоспалительных фракторов, что влияют на нитрозо-оксидативные процессы.

Цель исследования - изучить влияние витамина Е на нитрозо-оксидативные процессы в слизистых оболочках органов пищеварения крыс при действии низкоинтенсивного рентгеновского облучения и блокирования циклооксигеназы. 
Методы исследования. В гомогенатах слизистых оболочек желудка, тонкого и толстого кишечника крыс (n=64) определяли активность синтазы оксида азота, аргиназы, миелопероксидазы, супероксиддисмутазы, каталазы, содержание ТБК-активных продуктов, нитрит-аниона и сумму нитритов и нитратов.

Результаты и обсуждение. Установлено, что действие витамина Е на фроне низкоинтенсивного рентгеновского облучения приводило к снижению уровня активности индуцибельной синтазы оксида азота $(p<0,05)$ и содержания нитрит-аниона $(p<0,05)$ и повышению активности каталазы $(p<0,05)$ и миелопероксидазы $(p<0,05)$ по сравнению с показателями рентгеновского облучения. Блокирование активности циклооксигеназы индометацином на фроне введения витамина Е и одновременного действия низкоинтенсивного рентгеновского облучения выявило особенности антиоксидантного влияния витамина Е в слизистых оболочках органов пищеварения.

Выводы. В условиях блокирования циклооксигеназы индометацином на фроне низкоинтенсивного рентгеновского облучения уровень процессов липопероксидации возрастает, в то время как активность индуцибельной и конститутивной синтаз оксида азота уменьшается по сравнению с показателями при самостоятельном действии рентгеновского облучения, а по сравнению с данными при действии индометацина уровень процессов перекисного окисления липидов и активность индуцибельной синтазы оксида азота снижаются. Витамин Е проявляет антиоксидантное влияние при цитоповреждающем действии индометацина и на фроне действия рентгеновского облучения.

КЛЮЧЕВЫЕ СЛОВА: рентгеновское облучение; нитрозо-оксидативные процессы; слизистые оболочки органов пищеварения; витамин E.

Received 17.07.18

Address for correspondence: O. Ya. Sklyarov, Danylo Halytskyi Lviv National Medical University, Pekarska Street, 69, Lviv, 79010, Ukraine, e-mail: o.y.sklyarov@gmail.com. 